\title{
JILBAB \\ ANTARA KESALEHAN DAN FENOMENA SOSIAL
}

\author{
Safitri Yulikhah \\ Wartawan metrosemarang.com \\ Email: vitri.yulikha@gmail.com
}

\begin{abstract}
Close the genitals for a Muslim woman is a liability as embodied in the Qur'an. Clothes that cover the genitals is commonly called hijab. In the development of the hijab is not simply understood as a religious duty. However, it extends into the lifestyle of women in part. Hijab eventually not only a manifestation of piety as hoped religious orders. On the other hand hijab is a manifestation of social phenomena. This is reinforced by the widespread use of the hijab in some communities for reasons of politics, law, and others. Religious reasons behind the use of hijab among Muslim women. This reality ultimately refers to a conclusion that hijab is not merely a representation of Muslim piety but the hijab is also a life style for some Muslim women to be impressed or present a religious atmosphere in the life she lived.

Menutup aurat bagi seorang muslimah adalah kewajiban sebagaimana yang termaktub dalam al-Qur'an. Pakaian yang menutup aurat ini biasa disebut jilbab. Dalam perkembangannya jilbab bukan sebatas dipahami sebagai sebuah kewajiban agama. Namun meluas menjadi gaya hidup sebagaian perempuan. Jilbab akhirnya tidak hanya sebuah perwujudan kesalehan sebagaimana yang diharapkan perintah agama. Jilbab disisi lain merupakan manifetasi dari fenomena sosial. Hal ini diperkuat dengan maraknya penggunaan jilbab pada sebagian masyarakat karena alasan politik, hukum, dan lainnya. Beragama alasan yang melatarbelakangi penggunaan jilbab di kalangan muslimah. Realitas ini pada akhirnya merujuk pada sebuah kesimpulan bahwa jilbab bukan semata-mata representasi kesalehan muslimah. Tetapi jilbab juga menjadi life style bagi sebagian muslimah agar terkesan atau menghadirkan suasana religius dalam kehidupan yang dijalaninya.
\end{abstract}

Keywords: Hijab, Piety, Social Phenomenon 


\section{A. Pendahuluan}

Perempuan seringkali dianggap sebagai makhluk yang lemah, ketika perempuan melakukan aksi -dalam hal ini dicontohkan dengan mata yang lalang, dada yang terbuka karena tidak tertutup lapisan yang longgar atau pakaian dengan model leher rendah- maka reaksi dari lawan jenis yang lebih kuat akan menyebabkan ia kalah dan jatuh. Pendapat yang dikemukakan ini agaknya mewakili beberapa jika tidak bisa dikatakan sebagian besar pandangan terhadap perempuan ${ }^{1}$.

Pendapat tersebut juga diperkuat realitas yang menunjukkan bahwa perempuanlah yang cenderung menjadi objek seks -baik karena struktur psikologis maupun pendidikan sosial yang diterimanya- dibandingkan dengan pria. Hal ini karena sex appeal yang dimiliki perempuan dalam penampilan fisik tubuhnya dapat memicu rangsangan pada pria hingga merubah perempuan sebagai objek seks dalam realita menjadi fantasi seks, dan hal itu tidak berlaku secara umum bagi wanita yang melihat pria, karena pria sebagai objek seks dalam realita tidak lantas menjadi fantasi seks dalam pikiran perempuan. Hal tersebutlah yang kemudian diduga menjadikan Islam mewajibkan hijab atas wanita dan bukan atas pria, meski pada dasarnya pria juga merupakan objek seks dalam realita. ${ }^{2}$

Permasalahan pewajiban penggunaan jilbab bagi perempuan ini tidak lantas berhenti pada satu kesepakatan. Pembahasan mengenai masalah ini juga samai permasalahan aurat perempuan. Di mana masalah aurat ini juga menimbulkan perbedaan pendapat. Khususnya tentang batas-batas yang diperbolehkan bagi kaum perempuan untuk memperlihatkan anggota tubuhnya. Sebagian pakar menyatakan bahwa seluruh tubuh perempuan adalah aurat sehingga harus ditutup. Sementara sebagai pakar lain menyatakan bahwa wajah dan telapak tangan bukanlah aurat sehingga diperbolehkan untuk diperlihatkan.

Sampai pada cakupan yang cukup luas itulah jilbab menjadi bahan perdebatan, diskusi, hingga tolak ukur keimanan seseorang. Persoalan jilbab memang bukan hal baru, namun belakangan ini permasalahan tentang jilbab kembali mencuat. Terlebih dengan pemahaman yang menyebutkan bahwa Quraish Shihab sebagai seorang ulama reformis menyatakan ketidakharusan dalam berjilbab bagi perempuan. Namun, hal

1 Darby Jusbar Salim, Busana Muslim dan Permasalahannya, (Jakarta: Proyek Pembinaan Kemahasiswaan Dirjend Pembinaan Kelembagaan Agama Islam DEPAG RI, 1984), hal. 4.

2 Sayid Muhammad Husain Fadhlullah, Dunia Wanita dalam Islam, (Jakarta: Lentera, 2000), hal. 110. 
tersebut sudah dijawab olehnya bahwa ia hanya menjabarkan beberapa pendapat mengenai kewajiban berjilbab dan tidak atau belum menentukan pilihan akan mengikuti pendapat yang mewajibkan atau yang tidak mewajibkan. Menurutnya masalah jilbab tidak selalu harus dipandang dari wajib atau tidaknya. ${ }^{3}$

Tetapi bukan masalah wajib tidaknya jilbab yang ingin dikemukakan di sini, melainkan fenomena pemakaian jilbab oleh perempuan di masyarakatlah yang ingin dibahas. Agar diharapkan fenomena jilbab ini dapat dilihat tidak hanya dari segi normatif agama saja, tapi pada ranah lain yang lebih luas seperti psikologi sebagai salah satu dari bagian cabang ilmu sosial. Diharapkan dengan hal tersebut dapat diketahui pula alasanalasan perempuan yang memilih mengenakan atau tidak mengenakan jilbab.

Namun, meskipun bukan masalah legal formal tentang wajib atau tidaknya jilbab bagi perempuan muslim, pada realitanya aturan wajib inilah yang mendasari berbagai pembentukan persepsi di dalam masyarakat. Bahwa perempuan muslim atau muslimah yang baik dan taat adalah mereka yang mengenakan jilbab. Sehingga yang muncul kemudian adalah anggapan bahwa muslimah yang tidak berjilbab itu belum menjalankan agama secara benar jika tidak ingin menyebutnya tidak taat. Jadi kemudian jilbab dijadikan patokan bagi religius atau tidaknya seorang muslimah.

Tetapi jika melihat kondisi sekarang perempuan muslimah yang berjilbab tidaklah seideal, seanggun, apa yang digambarkan sebagai musimah taat. Shibab menyatakan ada perempuan-perempuan yang memakai jilbab namun tingkah lakunya tidak sejalan dengan tuntunan agama dan budaya masyarakat Islam. Perempuan berjilbab bisa berdansa dengan lelaki yang bukan muhrimnya. Jilbab dalam konteks ini disebut oleh Shihab sebagai mode berpakaian yang merambah kemana-mana dan bukan sebagai tuntunan agama. ${ }^{4}$

Kemudian muncul pertanyaan bagaimana dengan perempuan muslim yang tidak berjilbab. Benarkah mereka bukan perempuan yang taat dalam beragama, yang bisa dengan sembarang memamerkan tubuh mereka? Atau bahkan bagaimana dengan perempuan yang melepas jilbabnya setelah mereka dengan kukuh mempertahankan jilbabnya?

${ }^{3}$ M. Qurashi Shihab, Jilbab Pakaian Wanita Muslimah: pandangan ulama masa lalu dan cendekiawan kontemporer,( Jakarta: Lentera Hati, 2014), hal. xiv

4 Ibid., hal. ix 


\section{B. Pembahasan}

\section{Jilbab dan Konteks Sosial}

Banyak arti dari kata jilbab yang sebenarnya merupakan kosa kata bahasa Arab. Jilbab merupakan bentuk jamak dari jalaabiib yang artinya pakaian yang luas. Artinya adalah pakaian yang lapang dan dapat menutupi aurat wanita kecuali muka dan telapak tangan hingga pergelangan tangan saja yang ditampakkan. ${ }^{5}$ Ada pula Al-Biqa'i (dalam Thohari, 2011) yang menyebutkan beberapa arti dari kata jilbab yaitu baju yang longgar atau kerudung penutup kepala wanita, atau pakaian yang menutupi baju dan kerudung yang dipakainya, atau semua pakaian yang menutupi badan wanita. ${ }^{6}$

Berdasarkan pengertian itu maka dapat dikatakan bahwa jika yang dimaksud dengan jilbab adalah baju, maka jilbab adalah pakaian yang menutupi tangan dan kakinya. Kemudian jika ia adalah kerudung maka perintah mengulurkannya adalah menutup wajah dan lehernya. Selanjutnya jika maknanya pakaian yang menutupi badan maka perintah mengulurkannya adalah membuatnya longgar sehingga menutupi semua badan dan pakaian.

Jilbab dalam kamus besar bahasa Indonesia diartikan sebagai kerudung lebar yang dipakai muslimah untuk menutupi kepala dan leher hingga dada. Jilbab di Indonesia sendiri awalnya lebih dikenal dengan sebutan kerudung yaitu kain untuk menutupi kepala, namun masih memperlihatkan leher dan sebagian rambut. Baru pada awal tahun 1980an istilah jilbab mulai dikenal, yaitu kerudung yang juga menutup leher dan semua rambut. ${ }^{7}$

Demikian sekiranya berbagai pendapat tentang arti kata jilbab. Meskipun ada beragam pendapat mengenai jilbab, di sini penulis membatasi atau mengartikan jilbab sebagai kerudung perempuan yang menutupi kepala hingga dada. Sedangkan pakaian lebar yang menutupi badan dan aurat penulis sebut dengan hijab.

Saat ini jilbab sangat identik dengan busana perempuan muslim atau muslimah. Sehingga jika boleh disebut jilbab menjadi sebuah simbol

5 Fedwa El Guindi, Jilbab: Antara Kesalehan, Kesopanan, dan Perlawanan. Jakarta: Serambi, 2006), hal. 29

${ }^{6}$ Chamim Thohari, Konstruksi Pemikiran Quraish Shihab tentang Hukum Jilbab: Kajian Hermeneutika Kritis, (Malang: Jurnal Volume 14 Nomor 1 Januari - Juni 2011, Universitas Negeri Malang), hal. 78

7 Muhammad Said Al-Asymawi, kritik atas jilbab, terj. Nong Darol Mahmada, (Jakarta: JIL, 2003), hal. vii 
dari agama Islam. Namun, jika dilihat dari konteks sejarah ternyata bukan hanya agama Islam yang mengenal kata jilbab. Jilbab juga terdapat dalam kitab Taurat namun disebut dengan kata tif'eret, begitu pula dalam Injil ada istilah yang semakna dengan jilbab yaitu zammah, re'adah, juga zaif. Lebih jauh lagi ternyata penggunaan jilbab juga dikenal dalam hukum kekeluargaan Asyria. ${ }^{8}$ Sehingga dapat dikatakan bahwa masalah jilbab ini bukan masalah sederhana karena ia terkait dengan aspek pakaian wanita dan lintas budaya.

Istilah jilbab dalam perkembangannya fenomena jilbab membawa pesan beragam bukan hanya pada upaya pendefinisian istilahnya, tetapi juga pada pemberian makna dan penerapannya di masyarakat yang mengusung simbol sosial keagamaan dan identitas sosial. ${ }^{9}$

Bahkan fenomena jilbab ini menjadi isu internasional kala Pemerintah Perancis menetapkan larangan penggunaan simbol-simbol agama di sekolah-sekolah perancis, dan salah satu yang mereka nilai sebagai simbol agama adalah jilbab. ${ }^{10}$ Tidak hanya di Perancis, di Indonesia pada sekitar tahun 1980an atau pada masa pemerintahan Orde Baru, terdapat sebuah peraturan dari pemerintah yang menyatakan mengenai pelarangan penggunaan kain penutup kepala (jilbab).

Maret 1982, Departemen Pendidikan dan Kebudayaan (Departemen $\mathrm{P}$ dan K) Republik Indonesia mengeluarkan Surat Keputusan (SK) 052/C/Kep/D/82, yang mengatur bentuk dan penggunaan seragam sekolah di sekolah-sekolah negeri. Hal ini mengakibatkan semakin banyak siswi berjilbab mendapat teguran dan ancaman dari pihak sekolah. Bagi siswi yang tetap teguh menggunakan jilbab, mereka terpaksa harus keluar dari sekolah dan pindah ke sekolah swasta yang bisa mengizinkan mereka menggunakan jilbab tersebut. Pelarangan tersebut akhirnya menimbulkan berbagai kontra, akhirnya pada tahun 1991 keluar surat keputusan yang baru, yang memperbolehkan siswi mengenakan jilbab di lingkungan sekolah. ${ }^{11}$

Berdasarkan kasus tersebut, dapat diketahui bahwa di Indonesia jilbab tidak dipandang sebagai masalah agama, karena jika ia hanya dilihat sebagai masalah agama tentunya pelarangan jilbab ini menyalahi aturan

8 Ibid. hal. viii

9 Budiastuti, Jilbab dalam Perspektif Sosiologi: Studi Pemaknaan Jilbab di Lingkungan Fakultas Hukum Universitas Muhamaddiyah Jakarta. Tesis Tidak Diterbitkan. (Jakarta: Fakultas Ilmu Sosial dan Politik Program Pasca Sarjana Sosiologi, 2012), hal. 30

10 Muhammad Quraish Shihab, Jilbab Pakaian Wanita Muslimah: pandangan ulama masa lalu dan cendekiawan kontemporer, (Jakarta: Lentera Hati, 2014) hal. $\mathrm{x}$

${ }^{11}$ Alwi Alatas dan Fifrida Desliyanti, Revolusi Jilbab Kasus Pelarangan Jilbab di SMA Negeri se-Jabodetabek, 1982-1991, (Jakarta: I'tishom, 2001), hal. 17 
perundang-undangan tentang jaminan melaksanakan ajaran agama. Bahkan di masa lalu penggunaan jilbab hanya dilakukan oleh perempuan kampung dan terbatas dalam ruang dan waktu yaitu penggunaannya hanya pada saat tertentu semisal Idul fitri atau pengajian serta digunakan oleh perempuan yang sudah berhaji. ${ }^{12}$ Namun, saat ini jilbab telah menjadi fenomena gaya hidup yang tak lagi terbatas pada ruang dan waktu.

Perempuan dengan memakai tertutup yang menutupi seluruh tubuhnya akan melindungi dirinya dari godaan lawan jenis, hal ini tentu berbeda dengan perempuan yang memakai pakaian terbuka, laki-laki akan mudah tergoda apalagi pakaian yang menampakkan perhiasannya. ${ }^{13}$ Secara tidak langsung dapat diartikan bahwa perempuan yang tidak menutup tubuhnya (baca: tidak berjilbab) cenderung menjadi penyebab tergodanya laki-laki. Bahkan Suardi (1995) mengatakan bahwa perempuan yang rela menanggalkan jilbab dan memperlihatkan kaki serta leher jenjangnya untuk karirnya/pekerjaannya tengah mengalami apa yang disebutnya sebagai "tragedi keimanan". Baik Salim maupun Suardi, keduanya berpandangan bahwa perempuan muslim harusnya menjaga jilbabnya. ${ }^{14}$

Namun yang terjadi di masyarakat justru berbeda. Sekarang ini tidak sedikit perempuan berjilbab yang mengetuk satu pintu ke pintu lainnya dengan stopmap berisi permintaan sumbangan entah untuk pembangunan masjid atau panti asuhan. Tetapi, baik masjid atau panti asuhan itu diragukan keberadaanya. Hal ini pun dibenarkan oleh Suardi (1995) menurutnya jilbab telah diperalat sebagai kamuflase kejatidirian para penipu. Berangkat dari fakta tersebut, maka menurut hemat penulis, kurang tepat jika menjadikan jilbab sebagai titik tolak untuk mengukur kealiman seorang perempuan. ${ }^{15}$

Jilbab memiliki dua dimensi, yaitu materi dan rohani, jilbab materi berupa penutupan tubuh. Sedangkan jilbab rohani adalah kondisi dimana perempuan di tengah kehidupan masyarakat tidak berusaha tampil dengan dandanan yang menarik perhatian, dalam artian bahwa jilbab rohani ini adalah pencegah dari penyimpangan dan kemerosotan akhlak dan perilaku. Kedua dimensi ini dikatakan saling terikat dan memengaruhi, jilbab materi berfungsi sebagai imunitas atau kekebalan yang bersifat preventif sehingga jilbab rohani pun akan terjaga dengan terjaganya jilbab materi. ${ }^{16}$

12 Op.cit., Budiastuti, hal. 2

13 Op.cit., Darby Jusbar Salim, hal. 5

14 Dedy Suardi, Sang Kreator Agung, (Bandung: PT. Remaja Rosdakarya, 1995), hal.

15 Ibid., 238

16 Op.cit., Fadhlullah, hal. 109. 
Jadi, perempuan berjilbab peminta sumbangan tersebut dapat dikatakan bahwa ia hanya mengenakan jilbab materi saja dan bahkan menjadikannya sebagai kamuflase. Hal ini kemudian menimbulkan persepsi lain, yaitu munculnya apologi-apologi yang mengindikasikan bahwa jilbab rohani lebih penting dari pada jilbab materi. Seperti munculnya kalimat "lebih baik berpakaian biasa tapi hatinya baik, dari pada berpakaian muslimah tapi hatinya tidak baik". ${ }^{17}$ Berdasarkan pertimbangan tersebut, maka dapat dikatakan bahwa masalah jilbab ini bukan saja menyangkut masalah individu dengan keyakinannya, tetapi masalah sosial.

Diakui atau tidak, jilbab ini tidak hanya melulu soal agama tetapi bergulir dalam ranah sosial hingga politik. Di Indonesia sendiri jilbab mulai booming pada tahun 1990an berkat sumbangsih besar dari Cak Nun dengan roadshow keliling Indonesia mementaskan puisi Lautan Jilbab sebagai motor budaya, yang menjadikan perempuan Indonesia melirik jilbab. 18

Selain itu pula, fenomena para pelaku tindak pidana yang mulanya tidak berjilbab, tiba-tiba saja mengenakan jilbab. Sebut saja Wa Ode, Neneng Sri Wahyuni, Nunun Nurbaiti, Angelina Sondakh, sopir maut Apriyani. Mereka dalam kesehariannya tidaklah mengenakan jilbab, tetapi begitu mereka tersandung kasus tiba-tiba saja mereka mengenakan jilbab.

Setidaknya itulah sedikit gambaran tentang konteks sosial dari Jilbab, khususnya di Indonesia. Bahwa Jilbab yang diartikan sebagai pakaian teologi karena ada perintah agama yang menganjurkan perempuan menutup kepalanya -terlepas dari semua perbedaan pendapat yang menyertainya. Sebagai pakaian teologi, jilbab ini dijadikan semacam tameng atau pelindung bagi mereka yang merasa terancam baik dengan mengenakan atau melepas. Tetapi jilbab juga kemudian dijadikan komoditi dagang yang menggiurkan dengan menjadikan jilbab sebagai lifestyle. Sangat mungkin lifestyle tersebut berpengaruh positif, tetapi tidak pula menutup kemungkinan untuk melupakan nilai dasar agama tentang tata cara berpakaian, yaitu untuk tidak bertabarruj.

Jadi demikianlah jilbab menjalani eksistensinya dalam kehidupan manusia, bergerak dan berkembang seiring perkembangan dan kebutuhan manusia. Jilbab 'hidup' tak hanya dalam ranah agama tapi dalam berbagai ranah sosial manusia seperti ekonomi, psikologis, hingga politik.

\section{Alasan Pemakaian Jilbab}

17 Op.cit. Salim, hal. 7

18 Juneman. Psychology of Fashion Fenomena Perempuan (Melepas) Jilbab. (Yogyakarta: LKiS, 2011), hal.v 
Setelah menilik mengenai konteks sosial dari jilbab tentu dapat dilihat poin lain yang penting dan tak boleh ditinggalkan begitu saja. Hal tersebut adalah reason atau alasan. Ya alasan yang mendasari perempuan untuk berjilbab atau tidak berjilbab. Ada beragam alasan mengapa perempuan berjilbab, seperti: pertama karena alasan teologis baik itu karena proses perjuangan panjang sampai akhirnya meyakini bahwa jilbab adalah pakaian yang diwajibkan dalam Islam atau karena tekanan akan rasa takut pada dosa.

Kedua, berjilbab karena paksaan, semisal peraturan yang mewajibkan berjilbab seperti dalam lembaga-lembaga tertentu. Ketiga, karena alasan psikologis, misal tidak merasa nyaman karena semua orang di lingkungannya berjilbab atau karena ingin mencari rasa aman. Keempat, tuntutan gaya hidup, karena alasan modis atau lifestyle agar nampak cantik dan trendi, yang dibuktikan engan maraknya toko busana muslim. Keenam, alasan politis, yaitu memenuhi tuntutan kelompok Islam tertentu yang mengedepankan simbol-simbol agama sebagai dagangan politik. ${ }^{19}$

Bahkan hasil polling yang penulis lakukan untuk majalah kampus MISSI pada tahun 2014 menunjukkan hasil bahwa sebanyak 75\% mahasiswa di Fakultas Dakwah dan Komunikasi UIN Walisongo menyatakan bahwa jilbab merupakan bagian dari lifestyle yang berarti bahwa jilbab itu dianggap sebagai bagian dari gaya hidup. ${ }^{20}$ Berdasarkan hasil polling tersebut setidaknya dapat diketahui salah satu alasan mengapa para mahasiswa tersebut memakai jilbab.

Hal ini menunjukkan bahwa jilbab bukan lagi hanya masalah teologis. Bisa jadi mereka (perempuan yang mengenakan jilbab setelah mengalami masalah hukum) mengenakan jilbab karena alasan psikologis yaitu mencari rasa aman dari jilbab yang sudah dipersepsikan sebagai busana seorang muslimah yang baik. Sehingga mereka berharap akan mendapatkan simpati publik karena mereka adalah perempuan berakhlak baik karena jilbabnya yang dijadikan sebagai simbol kereligiusitasannya, setidaknya mungkin itulah harapan perseptual mereka.

Hal ini juga dipengaruhi oleh apa yang disebut dengan orientasi religius yaitu motif-motif di balik perilaku untuk memahami berbagai bentuk perbuatan yang dilakukan dalam menjalani ajaran agamanya. Orientasi religius ada dua yaitu orientasi ekstrinsik dan intrinsik. Orientasi ekstrinsik adalah sebuah orientasi religius yang memanfaatkan, mementingkan diri sendiri, berpusat pada keselamatan, status

19 Ibid., hal. viii

${ }^{20}$ Majalah Missi edisi 2014 
kenyamanan, dan protektifitas penganutnya. Sedangakn orientasi intrinsik adalah penginternalisasian keyakinan dan mengikuti ajaran-ajaran agamanya sehingga orang yang memiliki oreintasi intrinsik sering disebut sebagai orang yang sudah menemukan motif dasar dalam beragama. ${ }^{21}$

Sebuah tawaran pemahaman baru ditawarkan oleh Juneman melalui hasil penelitiannya tentang perempuan-perempuan yang melepas jilbabnya. Hasil penelitian Juneman tersebut ternyata menunjukkan bahwa jilbab tidak dapat menjadi tolak ukur tingkat religiusitas perempuan. Bahwa pola orientasi religius tidak memiliki kaitan dengan alasan seseorang mengenakan atau tidak mengenakan jilbab. ${ }^{22}$

Juneman menyatakan bahwa pemakaian jilbab oleh seorang muslimah dipengaruhi oleh kepercayaan eksistensial. Sebuah teori yang dikembangkan oleh Fowler dalam bukunya yang berjudul Stages of Faith: The Psychology of Human Development and The Quest for Meaning. Kepercayaan eksistensial ini merupakan konsep multidimensional yang meliputi kegiatan menciptakan makna (Meaning Making). Jadi kepercayaan eksistensial ini sangat erat hubungannya dengan kebutuhan manusia dalam mencari dan menciptakan makna. ${ }^{23}$

Pengalaman perempuan yang memakai jilbab atau tidak memakai jilbab secara khusus berkaitan dengan salah satu aspek dalam kepercayaan eksistensial yaitu aspek G kepercayaan eksistensial yakni fungsi simbolis dari jilbab itu sendiri. Namun, pemaknaan perempuan muslim terhadap jilbab sebagai aspek $\mathrm{G}$ tidak dapat dilepaskan dari perkembangan satu atau lebih aspek kepercayaan eksistensial lain. Yaitu aspek A (logika), Aspek B (Pengambilan perspektif sosial), Aspek C (bentuk pertimbangan moral), aspek D (batas-batas kesadaran sosial), Aspek E (lokus otoritas), Aspek F (bentuk koherensi dunia subjek).

Setelah subjek penelitian mengalami proses perkembangan kepercayaan eksistensial tersebut mereka menemukan makna baru dari jilbab yang semula mereka yakini sebagai jati diri muslimah. Sebagian memaknai jilbab hanya sebagai busana yang dapat dikenakan pada kondisi-kondisi tertentu dan tidak ada kaitannya dengan keimanan atau religiusitas mereka. Sedangkan sebagian yang lain masih setuju dengan makna jilbab sebagai jati diri muslimah, namun mereka menolak adanya pemaksaan dalam pemakaian jilbab bagi perempuan. ${ }^{24}$

${ }^{21}$ Diana Mumpuni, Analisis faktor-faktor Psikologis yang memengaruhi death anxiety, Jakarta: Universitas Islam Negeri Jakarta, 2014), hal. 41

22 Op.cit., Juneman, hal. 342

23 Ibid., hal. 56

24 Ibid., Juneman, hal. 340 
Berdasarkan hasil penelitiannya ini, Juneman menemukan hasil bahwa perempuan-perempuan yang dulunya berjilbab dan memaknai jilbab sebagai jati diri muslimah ini setelah mengalami pergulatan dalam hidupnya akhirnya menemukan makna baru tentang jilbab. Mereka tidak lagi memandang jilbab sebagai kewajiban tapi sebagai pakaian yang bisa mereka kenakan dan bisa mereka lepas. Di sini Juneman juga memaparkan bahwa religiusitas mereka (perempuan yang melepas jilbab) tidak lantas menjadi luntur atau pudar, bahkan mereka merasa menjadi lebih religius dan lebih dapat mendalami serta menghayati perintah-perintah agama.

Selain dengan kepercayaan eksistensial, pemakaian jilbab juga dapat dilihat melalui hierarki kebutuhan Maslow. Jika sebelumnya alasan pemakaian jilbab adalah untuk keamanan perempuan dari gangguan lelaki, maka sangat dimungkinkan alasan perempuan memakai jilbab adalah karena ia ingin merasa aman. Rasa aman ini dijelaskan Maslow dalam teori hieraki kebutuhannya.

Kebutuhan-kebutuhan ini disebut Maslow sebagai kebutuhan dasar yang digambarkan dengan sebagai sebuah hierarki atau tangga bertingkat yang menggambarkan tingkat kebutuhan. ${ }^{25}$ Hierarki kebutuhan Maslow ini memiliki lima tingkat yaitu kebutuhan fisiologis, kebutuhan akan rasa aman, kebutuhan rasa memiliki dan kasih sayang, kebutuhan akan penghargaan dan kebutuhan akan aktualisasi diri. 26

Tahap kedua dari hierarki kebutuhan Maslow ini yang coba penulis pakai sebagai pisau analisis dari pemakaian jilbab. Kebutuhan akan rasa aman ini muncul setelah kebutuhan fisiologis terpuaskan secukupnya. Kebutuhan akan rasa aman ini di antaranya adalah rasa aman fisik, perlindungan dan kebebasan dari daya yang mengancam seperti perang, terorisme, penyakit, kerusuhan, cemas, takut. Kebutuhan akan rasa aman ini berbeda dari kebutuhan fisiologis, karena kebutuhan akan rasa aman tidak dapat terpenuhi secara sempurna. ${ }^{27}$

Maslow mengatakan bahwa seseorang yang merasa tidak aman memiliki kebutuhan akan keteraturan dan stabilitas sehingga akan berusaha keras menghindari hal-hal asing yang tidak diharapkannya. ${ }^{28}$ Pemakaian jilbab ini, juga dapat dikatakan terkait dengan adanya konsep

${ }^{25}$ Jess Feits dan Gregory Feist, Teori Kepribadian, ( Jakarta: Salemba Humanika, 2010), hal. 331

${ }^{26}$ Dede Rahmat Hidayat, Teori dan Aplikasi Psikologi Kepribadian dalam Konseling, (Bogor: Ghalia Indonesia, 2011), hal. 166

27 Jess Feits dan Gregory Feist, loc.cit,

${ }_{28}$ G. Goble Frank, Psikologi Humanistik Abraham Maslow, (Yogyakarta: Kanisius, 1987), hal. 71 
menakuti dosa dan mengejar pahala juga surga dan neraka, yang seringkali dijadikan dasar dalam perintah berjilbab bagi anak-anak dalam dunia pendidikan. ${ }^{29}$ Konsep takut dosa inilah yang coba diatasi dengan mencari rasa aman. Rasa aman dari ketakutan akan dosa ini salah satunya dengan menggenakan jilbab yang dipahami sebagai perintah agama.

Tetapi, bagi mereka yang memilih tidak mengenakan jilbab juga memilki alasan tersendiri, rasa aman baginya tidak didapatkannya dari mengenakan jilbab. Justru saat ia mengenakan jilbab ia merasa tidak aman. Seperti yang dialami oleh wartawan yang meliput di daerah konflik, mereka melepas jilbabnya. ${ }^{30} \mathrm{Hal}$ ini terjadi karena kebutuhan akan rasa aman antara satu individu dengan individu lain berbeda. Lebih jauh lagi, pemakaian atau tidak memakai jilbab tidak berhenti pada tahapan kebutuhan akan rasa aman tapi juga merambah pada tahap kebutuhan akan penghargaan.

Kebutuhan akan penghargaan ini menurut Maslow memliki dua kategori, yaitu kebutuhan yang lebih rendah dan lebih tinggi. Kebutuhan yang rendah adalah kebutuhan untuk menghormati orang lain, kebutuhan akan status, ketenaran, kemuliaan, pengakuan, perhatian, reputasi, apresiasi, martabat, bahkan dominasi. Sedangkan kebutuhan yang lebih tinggi adalah kebutuhan akan harga diri termasuk perasaan, keyakinan, kompetensi, prestasi, penguasaan, kemandirian, dan kebebasan ${ }^{31}$

Saat ini jilbab yang telah bertranformasi menjadi gaya hidup dan bagian dari fashion ini menjadi salah satu cara bagi sebagian perempuan untuk memenuhi kebutuhannya akan penghargaan baik kebutuhan yang lebih rendah maupun lebih tinggi. Jika bisa mengambil contoh maka yang belum lama terjadi adalah konversi aktris Laudya Cintya Bella dari yang semula tidak berjilbab menjadi berjilbab. Setelah ia memutuskan untuk berjilbab, ia menjadi sorotan media yang mau tidak mau membuat ketenarannya meningkat mengingat statusnya yang merupakan publik figur.

Adapula Sefti Sanustika, istri dari Ahmad Fathonah -yang tengah tersandung kasus korupsi- memilih membuka jilbabnya dan mengenakan pakaian terbuka. Ada yang menduga pelepasan jilbab yang dilakukan oleh Sefti ini untuk kepentingan salah satu partai, maksudnya adalah untuk menunjukan status dari Sefti dan suaminya bahwa mereka bukan anggota

\footnotetext{
29 Op.cit. Juneman, Hal. 339

30 Ibid., hal. 360

31 Op.cit. Hidayat, hal. 167
} 
dari salah satu partai yang menaungi suaminya sebelum dibui. ${ }^{32}$ Tentu saja ini adalah pemisalan bahwa dengan mengenakan atau tidak mengenakan jilbab maka kebutuhan akan penghargaan dapat terpenuhi, dan tidak dimaksudkan untuk menilai atau mempertanyakan secara khusus apa alasan mereka mengenakan dan melepaskan jilbab.

Berdasarkan pemaparan tersebut, maka baik perempuan yang memakai atau tidak memakai jilbab memiliki alasan-alasan psikologis tertentu. Boleh jadi apa yang ditemukan Junemaan dalam penelitiannya terhadap perempuan yang melepas jilbab tentang perkembangan kepercayaan eksistensial juga dialami oleh perempuan-perempuan muslim. Bisa jadi mereka tengah mencari makna dari jilbab. Bisa pula karena mereka mencari rasa aman dan penghargaan dari pilihan mereka untuk memakai atau tidak memakai.

Tidak sedikit perempuan yang pada awalnya tidak memakai jilbab kemudian begitu menjadi mahasiswi dan mengenal bermacam organisasi keagamaan, akhirnya memutuskan berjilbab. Sebaliknya, mahasiswi yang dulunya berjilbab akhirnya setelah memasuki dunia perkuliahan akhirnya melepas jilbabnya. Jika pun tidak melepas, maka terjadi pergeseran bentuk dan jenis jilbab yang dikenakan. Tidak sedikit perempuan yang awalnya memakai jilbab besar kemudian seiring pergaulannya yang meluas maka ukuran jilbab yang dikenakan menjadi makin sempit.

Fenomena tersebut juga dialami oleh subjek penelitian Juneman. Mereka awalnya mengenakan jilbab besar lalu dalam proses melepas jilbab, ukuran jilbab mereka makin susut dan makin 'seadanya' hingga akhirnya melepas jilbab mereka. Hal tersebut setidaknya menunjukkan bahwa ada satu hal yang luput dari perhatian. Yaitu, tahukah perempuanperempuan tersebut tentang dalil-dail atau ayat-ayat seputar jilbab? Poin penting tersebut tertutup oleh doktrin-doktrin yang menyatakan bahwa jilbab itu wajib. Tetapi tidak dijelaskan lebih lanjut mengapa ia wajib? Sehingga tak sedikit yang menelan mentah-mentah perintah tersebut, maka berjilbablah para perempuan. Lantas menatap sinis saudara perempuan lain yang tidak berjilbab.

Selanjutnya, sebuah sanggahan yang muncul kemudian yang menyatakan bahwa jilbab tidak wajib karena rambut tidak lebih merangsang hawa nafsu bagi laki-laki dari pada bagian tubuh perempuan yang lain. Maka mereka yang tidak berjilbab punya argument untuk mendukung mereka yang tidak berjilbab. Atau setidaknya untuk melawan

32 Abd. Ghofar Al Amin, Demi PKS Istri Ustadz Fathanah Rela Lepas Jilbab. (Kompasiana, 2014) diakses dari kompasiana.com pada 29-11-2015 pukul 09.31 
tatapan sinis orang-orang yang menganggap mereka tidak melakukan perintah agama.

Namun, lagi-lagi kajian yang dilakukan oleh kaum perempuan untuk memahami baik bagi yang berpendapat kewajiban mengenakan jilbab atau yang tidak mewajibkan, bisa belum terlalu memadai. Hingga terkesan hanya mengikuti tren saja. Seperti diungkapkan Fachrudin dalam artikelnya di Jakarta Post bahwa banyak perempuan muslim Indonesia menggunakan jilbab hanya untuk mengikuti tren dan tradisi atau sekadar mengikuti budaya popular dengan adanya komunitas muslim..$^{33}$

Sangat dimungkinkan banyak perempuan muslim yang sebenarnya belum mengetahui dalil-dalil seputar jilbab. Sehingga mereka tidak memakai, dan boleh jadi mereka yang memakai pun sebenarnya belum mengetahui secara menyeluruh alasanna memakai jilbab. Seperti dipaparkan sebelumnya alasan memakai jilbab bisa jadi karena paksaan. Maka bisa jadi alasan berjilbab karena paksaan lembaga, misal sekolah yang mewajibkan siswinya untuk berjilbab. Sehingga mereka tidak sempat atau merasa tidak perlu untuk mencari tahu ayat-ayat seputar jilbab tersebut.

Tetapi pendapat tersebut tentu saja tidak bisa digeneralisasi pada setiap perempuan muslim. Hal ini karena banyak pula perempuan muslim yang berjilbab setelah melakukan pencarian yang mendalam tentang jilbab. Sampai akhirnya memutuskan untuk berjilbab. Tidak sedikit pula yang sudah tahu tentang ayat-ayat seputar jilbab, dan berjilbab pada awalnya kemudian karena berbagai pengalaman hidunya akhirnya memutuskan untuk melepas jilbabnya, seperti yang dialami oleh objek penelitian Juneman.

Masih, berdasarkan hasil polling yang penulis pernah lakukan pada tahun 2014 untuk sebuah majalah kampus MISSI, hasil polling sebesar 46.7\% mahasiswi di salah satu fakultas, di Perguruan Tinggi Islam mengatakan bahwa mereka tidak mengenakan pakaian muslim saat berada di luar kampus. Sementara sebagian besar responden merupakan lulusan pondok pesantren yang memberikan asumsi bahwa mereka mengetahui ayat-ayat seputar jilbab.

Hal tersebut menunjukkan bahwa dengan mengetahui ayat-ayat seputar jilbab saja ternyata tidak cukup memadai untuk menjawab fenomena jilbab tersebut. Sehingga menjadikan tahu atau tidaknya perempuan muslim tentang ayat-ayat seputar jilbab tidaklah cukup untuk

${ }^{33}$ Azis Anwar Fachruddin, Jilbab Phenomenon Religious or Cultural, (Yogyakarta: thejakartapost.com, 12/09/2014), Diakses dari thejakartapost.com pada 29-11-2015, pukul 10.00 wib 
menjelaskan fenomena jilbab ini. Hal ini karena seperti dijelaskan di awal bahwa ada beragam alasan yang menjadikan perempuan memilih memakai atau tidak memakai jilbab.

\section{Penafsiran Ayat-Ayat Seputar Jilbab}

Setelah membahas mengenai alasan perempuan mengenakan jilbab dan tidak mengenakan, selanjutnya penulis mencoba memaparkan beberapa ayat seputar jilbab. Namun, seperti kebanyakan permasalahan lain yag sellau menimbulkan pro dan kontra, jilbab juga demikian ada yang sepakat ada yang tidak sepakat. Permasalahan mengenai pakaian perempuan dalam hal ini adalah jilbab, ada dua kelompok yang memiliki pandangan berbeda.

Kelompok pertama mengungkapkan pendapatnya bahwa tanpa dalil keagamaan atau jika pun ada dalil maka itu sangat lemah dan tidak sejalan dengan kaidah-kaidah serta disiplin ilmu agama. Maka hal semacam itu tentu saja tidak dapat diterima. Kelompok kedua merujuk pada kaidahkaidah keagamaan yang juga diakui oleh pada ulama, hanya saja dalam penerapannya antara lain dalam konteks pakaian/aurat tidak mendapat dukungan ulama terdahulu, dan sebagian ulama kontemporer. ${ }^{34}$

Ada penganut pendapat kelompok pertama ini yang mengungkapkan bahwa pakaian tertutup merupakan salah satu bentuk perbudakan dan lahir ketika pria menguasai dan memperbudak perempuan. Ada pula yang berkata hijab yang bersifat material atau pakaian tertutup atau yang bersifat immaterial atau keduanya bersama-sama telah menutup keterlibatan perempuan dalam kehidupan, politik, agama, akhlak dan lainlain. Bahkan ada yang terang-terangan mengatakan bahwa ia menolak hijab, karena tertutup atau telanjang keduanya menjadikan perempuan sebagai jasad semata. Pendapat-pendapat tersebut mereka kemukakan atas dasar subjektivitas belaka dan tanpa dalil.35

Agaknya banyak perempuan muslim yang mengikuti dan mengamini kedua pendapat tersebut tanpa menelaah lebih jauh asalan kedua pendapat tersebut muncul. Oleh karena itu, berikut ini penulis memaparkan beberapa ayat seputar jilbab yang sering dipakai para ulama untuk dijadikan dasar bagi pemakaian jilbab. Terlepas dari bermacamnya perbedaan pendapat tentang penafsiran ayat tersebut. Namun, dengan

\footnotetext{
34 Op.cit. Shihab, 2014, hal. 172

35 Ibid., hal. 173
} 
perbedaan penafsiran diharapkan dapat membuka pemahaman tentang perintah berjilbab tersebut.

Ayat-ayat yang dijadikan rujukan perintah berjilbab, ayat pertama ini dipakai oleh para ulama sebagai dasar dalam menetapkan batas aurat wanita, yaitu firman Allah dalam QS. An-Nur [24]: 31.

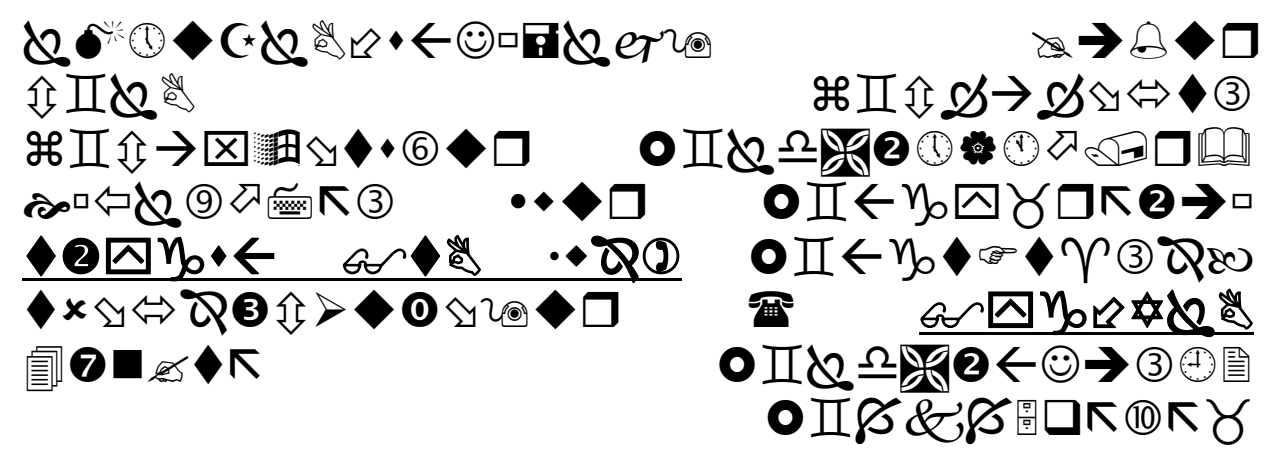

"Katakanlah kepada wanita yang beriman: "Hendaklah mereka menahan pandangannya, dan kemaluannya, dan janganlah mereka menampakkan perhiasannya, kecuali yang (biasa) nampak dari padanya. Dan hendaklah mereka menutupkan kain kudung kedadanya..."

Perbedaan pendapat muncul di kalangan ulama dalam memaknai kalimat illa ma zhahara minha (kecuali apa yang nampak darinya (perhiasannya). Ada banyak interpretasi dari ayat ini. Ath-Thabari, menyatakan bahwa kunci dari perbedaan pendapat yang ada di kalangan ulama adalah kata illa ma zhahara minha, baginya kontroversinya adalah tentang bagian apa dari tubuh perempuan yang boleh dibuka. Ia mengutip beberapa pendapat dari sahabat Nabi yang berpendapat bahwa hanya pakaian luarnya saja yang boleh diekspos oleh perempuan sedangkan seluruh badan termasuk wajah dan telapak tangan harus tertutup. Sebagian pendapat lain mengatakan bahwa perempuan dapat mengekspos matanya, cincin, gelang dan wajahnya. ${ }^{36}$

Ar-Razi berpendapat bahwa perempuan boleh memperlihatkan wajah dan tangannya karena baik wajah maupun tangannya diperlukan secara fungsional semisal jual beli. Namun menurutnya melihat wajah perempuan dengan penuh nafsu tidak dibolehkan. Jadi boleh melihat wajah perempuan jika tidak ada keinginan dengan apa yang disebut fitnah. Hal ini

${ }^{36}$ Asghar Ali Engineer, Pembebasan Perempuan, (Yogyakarta: LKiS, 2007), hal. 86 
karena ayat ini juga menunjukkan bahwa Alquran ingin melindungi perempuan dari pelecehan seksual dan eksploitasi. 37

Muhammad Asad, mengatakan bahwa illa ma zhahara minha sebagai apa yang oleh manusia boleh ditunjukkan secara terbuka sesuai dengan adat kebiasaan yang ada. Baginya kekaburan dalam ungkapan ini adalah kesengajaan yang dimaksudnkan untuk mengizinkan semua masa untuk mengadakan perubahan yang dibutuhkan dalam pertumbuhan moral dan sosial manusia. ${ }^{38}$

Menanggapi perbedaan pandangan para mufasir sebelumnya, Quraish Shihab berpendapat bahwa masing-masing penganut pendapat di atas sebatas menggunakan logika dan kecenderungannya serta dipengaruhi secara sadar atau tidak dengan perkembangan dan kondisi sosial masyarakatnya. Batas aurat wanita tidaklah secara jelas ditegaskan dalam ayat tersebut. Sehingga ayat tersebut tidak seharusnya menjadi dasar yang digunakan untuk menetapkan batas aurat wanita. ${ }^{39}$

Shihab menyatakan bahwa perbedaan pendapat para pakar maasa lalu tentang batas-batas yang boleh da tidak boleh dilihat dari perempuan tersebut, membuktikan bahwa mereka tidak sepakat dengan nilai keshahihan riwayat yang ada dan hal ini sekaligus menunjukkan bahwa ketetapan hukum tentang abtas yang diperbolehkan itu bersifat zhanniy atau dugaan. Hal ini berarti dugaan tesebut bisa jadi dinilai kuat oleh salah satu pihak tapi dinilai lemah oleh pihak lain. Shihab menambahkan bahwa jiaka ada hukum pasti yang bersumber dari Alquran dan hadis maka tidak akan ada perbedaan pendapat dalam menentukan luas sempitnya batasbatas tersebut. 40

Sementara dalam memahami kalimat illa ma zhahara minha, Shihab berpendapat bahwa sangat penting untuk menjadikan adat kebiasaan sebagai pertimbangan dalam penetapan hukum, namun dengan catatan adat tersebut tidak lepas kendali dari prinsip-prinsip ajaran agama serta norma-norma umum. Hal tersebut karena itu ia sampai kepada pendapat bahwa pakaian adat atau pakaian nasional yang biasa dipakai oleh putriputri Indonesia yang tidak mengenakan jilbab tidak dapat dikatakan sebagai telah melanggar aturan agama. ${ }^{41}$

37 Ibid., hal. 88

38 Ibid., 90

39 Muhammad Quraish Shihab, Tafsir Al-Misbah: Pesan, Kesan dan Keserasian alQur'an, (Jakarta: Lentera Hati, cet 6, Jilid 5 dan 9), hal. 67

40 Op.cit. Shihab, 2014, hal. 234

41 Muhammad Quraish Shihab, Wawasan al-Qur'an: Tafsir Maudhu'i atas Berbagai Persoalan Umat. (Bandung: Mizan, 1996), hal. 179 
As-Sayyid Salim (2014) memberikan kesimpulan tentang perbedaan dua kubu ulama ini, bahwa ulama sepakat pada wajibnya menutup tubuh perempuan merdeka selain wajah dan telapak tangan. Namun berkaitan dengan wajah dan telapak tangan terjadi perbedaan pendapat. Kemudian ulama yang tidak mewajibkan menutup wajah berpendapat bahwa menutup wajah lebih utama dan lebih banyak dilakukan pada zaman fitnah. ${ }^{42}$

Masih dalam ayat yang sama, juga terdapat kalimat sebagai berikut:

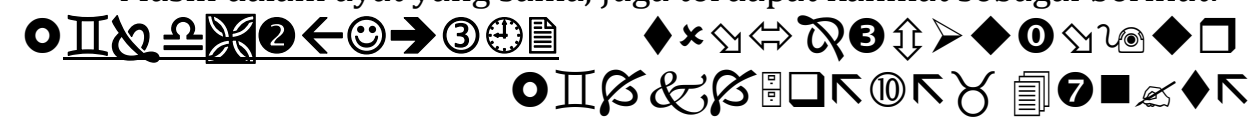

Artinya: hendaklah mereka (perempuan) meletakkan (secara mantap) kerudung mereka di atas lubang baju mereka (dada).

Pada ayat di atas terdapat kata khumurihinna yang berasal dari kata khumur bentuk jamak dari kata khimar. Sesuatu yang diletakkan di atas kepala untuk menutupinya disebut khimar. Berangkat dari sinilah khimar kemudian diartikan sebagai kerudung.

Akan tetapi kemudian muncul pertanyaan baru, benarkah dengan menutup kepala dan dada dengan khimar merupakan pesan dari ayat tersebut atau hanya menutup dada dengan cara apapun meski tidak menutup kepala. Bila merujuk redaksi ayat tersebut perintah yang diserukan adalah menutup dada perempuan dengan kerudung mereka. Sehingga menimbulkan kesimpulan sementara bahwa rambut perempuan tidak wajib ditutup karena ayat ini menekankan pada pentingnya menutup dada.

Ayat selanjutnya yang menjadi bahasan pokok tentang pakaian wanita, yaitu firman Allah dalam QS. Al-Ahzab [33]:59.

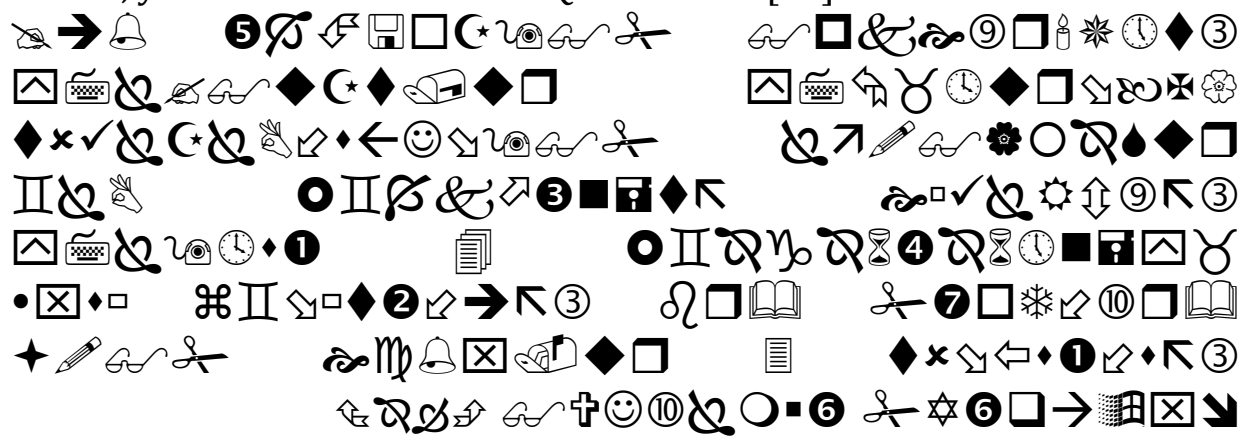

42 Abu Malik Kamal bin As Sayyid Salim, Fiqhus Sunnah Lin Nisa Panduan Fikih Lengkap Bagi Wanita Menguraikan Hukum-hukum Fikih yang Wajib Diketahui oleh Setiap Muslimah, (Solo: Pustaka Arafah, 2014), hal. 353 
Artinya: Wahai Nabi, Katakanlah kepada isteri-isterimu, anak-anak perempuanmu dan isteri-isteri orang mukmin: "Hendaklah mereka mengulurkan jilbabnya (ke seluruh tubuh mereka)". Yang demikian itu supaya mereka lebih mudah untuk dikenal, Karena itu mereka tidak di ganggu. dan Allah adalah Maha Pengampun lagi Maha Penyayang.

Ketika membaca ayat ini juga muncul masalah tentang makna jilbab, karena di sini para mufasir berbeda pendapat. Hampir semua ulama sepakat bahwa perintah ayat di atas berlaku bukan saja pada zaman Nabi SAW, tetapi juga sepanjang masa hingga kini dan masa yang akan datang. Namun sementara ulama kontemporer memahaminya hanya berlaku pada zaman Nabi SAW di mana ketika itu ada perbudakan dan diperlukan adanya pembeda antara mereka dan wanita-wanita merdeka, serta bertujuan menghindarkan gangguan lelaki usil. Menurut ulama kontemporer, jika tujuan tersebut telah dapat dicapai dengan satu dan cara lain, maka ketika itu pakaian yang dikenakan telah sejalan dengan tuntunan agama. Mereka beranggapan bahwa ayat ini turun pada situasi tertentu, di mana pada saat itu budak-budak perempuan bisa digoda, sedangkan perempuan merdeka bisa juga dianggap sebagai budak karena pakaian yang mereka kenakan. ${ }^{43}$

Terlepas apapun makna jilbab yang diyakini oleh tiap-tiap mufasir, yang lebih penting menurut Quraish Shihab adalah apakah perintah mengulurkan jilbab pada ayat tersebut berlaku hanya pada zaman Nabi SAW atau berlaku sepanjang masa? Quraish Shihab memahami perintah tersebut hanya berlaku pada zaman Nabi SAW, ketika itu ada perbudakan dan diperlukan adanya pembeda antara mereka dan wanita-wanita merdeka, serta bertujuan menghindarkan gangguan lelaki usil. Menurutnya, sebelum turunnya ayat ini, cara berpakaian wanita merdeka atau budak-yang baik-baik atau yang kurang sopan hampir dapat dikatakan sama. Karena itu lelaki usil sering kali mengganggu wanitawanita khususnya yang mereka ketahui atau duga sebagai sahaya. Untuk menghindarkan gangguan tersebut, serta menampakkan keterhormatan wanita muslimah ayat di atas turun. ${ }^{4}$

Berdasarkan pemaparan mengenai ayat dan penafsiran ulama tersebut, tentu dapat dilihat alasan mereka yang mewajibkan dan alasan yang tidak mewajibkan. Shibab sebagai ulama kontemporer yang dapat dikatakan memiliki pengaruh besar, dalam membangun argumennya

\footnotetext{
43 Op.cit., Engineer, hal. 88

${ }^{44}$ Op.cit. Shihab, 2006, hL. 309
} 
menggunakan beberapa pendekatan dan metode yang dapat digunakan dalam berijtihad, yaitu:

Pertama, pendekatan tarjih, yang dapat diartikan sebagai upaya menyeleksi beragam pendapat yang berasal dari beragam madzhab, kemudian diambil pendapat yang rajih, berdasarkan kriteria yang telah ditentukan dan yang dapat diterima.

Kedua, Pendekatan 'illat al-hukm, 'illat adalah suatu sebab dimana hukum itu diterapkan. Adapun syarat utamanya adalah suatu 'illat hukum mesti jelas, konsisten dan sesuai dengan maqashid syari'ah, yaitu membawa kemaslahatan. Alasan turunya QS. al-Ahzab (59) menurutnya adalah untuk membedakan antara perempuan muslim dan hamba sahaya serta menghindari gangguan lelaki usil. Sedangkan pada masa sekarang sudah tidak ada lagi perbudakan sehingga tidak ada hamba sahaya. Sehingga berpakaian nasional dengan penampakan rambut serta setengah betis bagi wanita dapat dibenarkan. Hal itu disebabkan karena ketidaan 'illat hukum dapat membatalkan diterapkannya hukum.

Ketiga, Metode istihsan (bi al-'Urf), karena Shihab menyatakan untuk menjadikan adat kebiasaan sebagai pertimbangan dalam penetapan hukum (dengan catatan adat tersebut tidak lepas kendali dari prinsip-prinsip ajaran agama serta norma-norma umum), dan menggunakan alasan diamnya ulama Indonesia pada masa lalu melihat cara berpakaian wanita muslimah yang cenderung tradisionalis (tanpa memakai jilbab) sebagai bentuk kesepakatan dari cara berpakaian wanita muslimah ketika itu. 45

\section{Kesimpulan}

Seperti telah dipaparkan pada bagian sebelumnya, bahwa jilbab memiliki ranah yang cukup luas dalam kehidupan sosial manusia. Selain sebagai sebuah busana yang menjadi simbol keagamaan jilbab dengan luwesnya merambah pada ranah-ranah lain. Perbedaan pendapat juga turut meramaikan permasalahan jilbab ini. Jilbab yang diartikan sebagai kerudung yang menutup kepala hingga dada perempuan memang penuh paradoks sebagaimana ditunjukkan Makhlouf (dalam Juneman, 2011):

"Jilbab walaupun jelas-jelas merupakan pembatasan komunikasi (dia juga adalah simbol) alat komunikasi dan berjilbab tentunya menciptakan suatu perintang bagi ekspresi

45 Op.cit. Thohari, hal. 82-84 
bebas perempuan sebagai seorang pribadi (tapi jilbab juga mengingkatkan) ekspresi diri dan feminitas" 46

Penulis sependapat dengan Makhlouf, bahwa jilbab memang penuh paradoks. Di satu sisi jilbab dianggap sebagai pembatas dalam komunikasi tapi ia juga merupakan simbol komunikasi nonverbal. Kemudian jilbab juga enjadi semacam penghalang bagi bentuk ekspresi bebas perempuan tapi bagi sebagian perempuan lain jilbab justru merupakan peningkat dari ekspresi diri dan symbol feminitas. Jilbab yang sejatinya sedarhana menjadi memiliki beragam makna yang bernbeda-beda, seiring dengan usaha manusia untuk memaknainya.

Penulis memaknai jilbab sebagai produk budaya yang diperkuat dengan anjuran Agama dengan alasan untuk perlindungan atau kemashlahatan, namun penulis tidak sependapat jika jilbab dijadikan sebagai titik tolak tingkat kereligiusan seseorang. Tidak ada jaminan bahwa pemakai jilbab adalah perempuan shalehah, dan sebaliknya perempuan yang tidak memakai jilbab bukan perempuan shalehah. Hal ini karena jilbab tidak identik dengan kesalehan dan ketaqwaan seseorang konstruksi sosiallah yang memberikan "label" pada jilbab. ${ }^{47}$

Meskipun memakai atau tidak memakai jilbab adalah pilihan, namun Islam sudah dengan jelas mengatur bagaimana tata cara pergaulan dengan manusia (habluminannas). Jadi apabila memilih untuk tidak berjilbab, maka hendaklah tetap bergaul dan bertingkah laku seperti yang sudah diatur dalam syariat. Sedangkan bagi yang memilih berjilbab maka tindaktanduknya pun harus senada dengan busana yang dipilihnya yaitu busana yang bertujuan untuk membentengi dirinya dari godaan-godaan yang bisa saja mengganggu.

Selain itu pula perempuan yang memilih memakai atau tidak memakai hendaknya mempelajari dan mencari tahu tentang dalil-dalil seputar jilbab. Sehingga apa yang akan dipilih bukanlah pilihan kosong tanpa arti.

46 Op.cit. Juneman, hal. 32

47 Ibid., hal. xiii 


\section{DAFTAR PUSTAKA}

Al Amin, Abd. Ghofar. 2014. Demi PKS Istri Ustadz Fathanah Rela Lepas Jilbab. Kompasiana, diakses dari kompasiana.com pada 29-11-2015 pukul 09.31

Alatas, Alwi, Fifrida Desliyanti. 2001. Revolusi Jilbab Kasus Pelarangan Jilbab di SMA Negeri se-Jabodetabek, 1982-1991. Jakarta: I'tishom.

Al-Asymawi, Muhammad Said. 2003. Kritik Atas Jilbab, terj. Nong Darol Mahmada, Jakarta: JIL

Budiastuti. 2012. Jilbab dalam Perspektif Sosiologi: Studi Pemaknaan Jilbab di Lingkungan Fakultas Hukum Universitas Muhamaddiyah Jakarta. Tesis Tidak Diterbitkan. Jakarta: Fakultas Ilmu Sosial dan Politik Program Pasca Sarjana Sosiologi.

El Guindi, Fedwa. 2006. Jilbab: Antara Kesalehan, Kesopanan, dan Perlawanan. Serambi

Engineer, Asghar Ali. 1999. Pembebasan Perempuan. Yogyakarta: LKiS

Fachruddin, Azis Anwar. 2014. Jilbab Phenomenon Religious or Cultural, (Yogyakarta: thejakartapost.com, 12/09/2014), Diakses dari thejakartapost.com pada 29-11-2015, pukul $10.00 \mathrm{wib}$

Fadhlullah, Sayid Muhammad Husain. 2000. Dunia Wanita dalam Islam. Jakarta: Lentera

Feist, Jess dan Gregory J. Feist. 2010. Teori Kepribadian: Theories of Personality. Bandung: Salemba Humanika

Frank, G. Goble. 1987. Psikologi Humanistik Abraham Maslow. Yogyakarta: Kanisius

Hidayat, Dede Rahmat. 2011. Teori dan Aplikasi Psikologi Kepribadian dalam Konseling. Bogor: Ghalia Indonesia 
Juneman. 2010. Psychology of Fashion Fenomena Perempuan (Melepas) Jilbab. Yogyakarta: LKiS

Mumpuni, Diana. 2014. Analisis Faktor-faktor Psikologis yang Memengaruhi Death Anxiety, Jakarta: Universitas Islam Negeri Jakarta

Rusli, Ris'an. 2014. Pembaharuan Pemikiran Modern dalam Islam. Jakarta: Rajawali Pers.

Salim, Abu Malik Kamal bin As Sayyid. 2014. Fiqhus Sunnah Lin Nisa Panduan Fikih Lengkap Bagi Wanita Menguraikan Hukum-hukum Fikih yang Wajib Diketahui oleh Setiap Muslimah Solo: Pustaka Arafah.

Salim, Darby Jusbar. 1984. Busana Muslim dan Permasalahannya. Jakarta: Proyek Pembinaan Kemahasiswaan Dirjend Pembinaan Kelembagaan Agama Islam DEPAG RI.

Shihab, M. Qurashi. 1996, Wawasan al-Qur'an: Tafsir Maudhu'i atas Berbagai Persoalan Umat. Bandung: Mizan

, 2006. Tafsir Al-Misbah: Pesan, Kesan dan Keserasian al-Qur'an. Jakarta: Lentera Hati, cet 6, Jilid 5 dan 9.

2014. Jilbab Pakaian Wanita Muslimah: pandangan ulama masa lalu dan cendekiawan kontemporer. Jakarta: Lentera Hati

Suardi, Dedy. 1995. Sang Kreator Agung. Bandung: PT. Remaja Rosdakarya

Thohari, Chamim. 2011. Konstruksi Pemikiran Quraish Shihab tentang Hukum Jilbab: Kajian Hermeneutika Kritis. Malang: Jurnal Volume 14 Nomor 1 Januari - Juni 2011, Universitas Negeri Malang. 